\title{
A STUDY OF EFL STUDENTS' ORAL COMMUNICATION STRATEGIES IN DISCUSSIONS
}

\author{
Rosi Hardianti \\ Department of English Education, University of Kuningan \\ Email: rosihardianti12@gmail.com
}

APA Citation: Hardianti, R. (2016). A study of EFL students' oral communication strategies in discussions. Indonesian EFL Journal, 2(1), 23-33

\begin{abstract}
Received: 19-11-2015
Accepted: 24-12-2015

Published: 01-01-2016

Abstract: In the process of communication, EFL students frequently experience problem in saying what they want to say in English. Oral Communication Strategies (OCS) surface as the students needs to solve problems of expressing their intended meaning. This descriptive qualitative study intended to analyze (1) types of OCS used by students while conducting discussion, and (2) the students' reasons for using certain types of OCS. The participants of this study were a group discussion consisting of five EFL students of English Education Department in the University of Kuningan. The data in this study were gained from observation and interview which were then transcribed. The data were analyzed qualitatively by using Dornyei's (1995) taxonomy of OCS. The results revealed that students participated in this study tended to use achievement strategies $(73.07 \%)$ more frequently than avoidance strategies $(26.92 \%)$. Specifically, students used nine out of twelve communication strategy types, and the most frequent strategy used by students while conducting discussion was the use of fillers strategy (51.28\%). Then, the students' reasons for using fillers strategy in their communication were basically because of their lack of English vocabulary knowledge and content knowledge of topics which were being discussed. Thus, students encounter communication problems as the results of target linguistic inadequacy. Hence, further study might yield different result if the topics chosen for discussion were desired topics among students.
\end{abstract}

Keywords: EFL (English as a foreign language), oral communication strategies, discussion

\section{INTRODUCTION}

Learning a foreign language includes the ability to communicate. For English language learners, they are going to be put in situations where communication in English is needed (Khadidja, 2010). The need for English speaking mastery has been increased due to the status of English as a global language recognize in every country (Crystal, 2003). However, communication is one of the crucial skills that challenge the EFL (English as Foreign Language) learners to different degrees. There is often a lack of communication in EFL classroom which leads to the inability to communicate in a native-like way even after several years of learning the language (Flyman, 1997). Besides, foreign language speaking differs from first language speaking in terms of the lack of grammar and vocabulary knowledge of the learners (Khadidja, 2010). As a result, English language learners frequently experience problems in saying what they want to say.

In the process of communication, learners may come across a great number of problems without doubt (Wei, 2011). To make communication smooth, therefore, learners must find some effective ways to communicate their 


\section{Rosi Hardianti}

A Study of EFL Students' Oral Communication Strategies in Discussions

thoughts. Whenever the learner experiences a problem because of the limitation of linguistic resources, learners may use strategic competence. Strategic competence is the crucial element in communicative competence since it refers to language learners' ability to use communication strategies either to solve communication problems or to enhance the effectiveness of communication (Brown, 2000).

Oral Communication Strategies (OCS) is regarded as useful tools to keep the communication channel open (Moattarian, 2012). Corder (1981, in Dornyei, 1995, p.56) defines oral communication strategy as "a systematic technique employed by a speaker to express his or her meaning when faced with some difficulty". Avoidance strategies and compensatory strategies are two sub types of OCS that can be used by learners in practicing oral communication whenever communication problems occur. If learners do not know a word in the target language they may 'borrow' a word from their L1, or use another target-language word that is approximate in meaning, or try to paraphrase the meaning of the word, or even construct an entirely new word (Ellis, 1997). In other word, when language learners do not know how to say a word in English, they can communicate effectively by using their hands, imitating sounds, mixing languages, inventing new words, or describing what they mean (Dornyei, 1995).

Table 1. Dornyei's taxonomy of OCS (1995)

\begin{tabular}{|c|c|c|}
\hline No & Types of CS & Description \\
\hline 1. & $\begin{array}{l}\text { Message } \\
\text { Abandonment }\end{array}$ & $\begin{array}{l}\text { Leaving a message unfinished because of language } \\
\text { difficulties. }\end{array}$ \\
\hline 2. & Topic Avoidance & $\begin{array}{l}\text { Avoiding topic areas or concepts which pose language } \\
\text { difficulties. }\end{array}$ \\
\hline 3. & Circumlocution & $\begin{array}{l}\text { Describing or exemplifying the target object or action } \\
\text { (e.g., the thing you open bottles with for corkscrew). }\end{array}$ \\
\hline 4. & Approximation & $\begin{array}{l}\text { Using an alternative term which expresses the } \\
\text { meaning of the target lexical item as closely as } \\
\text { possible (e.g., ship for sail boat). }\end{array}$ \\
\hline 5. & $\begin{array}{l}\text { Use of All- } \\
\text { Purpose Words }\end{array}$ & $\begin{array}{l}\text { Extending a general, empty lexical item to contexts } \\
\text { where specific words are lacking } \\
\text { (e.g., the overuse of thing, stuff, make, do, as well as } \\
\text { using words like thingie, what-do-you-call-it). }\end{array}$ \\
\hline 6. & Word Coinage & $\begin{array}{l}\text { Creating a non-existing L } 2 \text { word based on a supposed } \\
\text { rule (e.g. vegetarianist for vegetarian, paintist for } \\
\text { painter). }\end{array}$ \\
\hline 7. & $\begin{array}{l}\text { Use of Non- } \\
\text { Linguistic Means }\end{array}$ & Mime, gesture, facial expression, or sound imitation. \\
\hline 8. & $\begin{array}{l}\text { Literal } \\
\text { translation }\end{array}$ & $\begin{array}{l}\text { Translating literally a lexical item, an idiom, a } \\
\text { compound word or structure from LI to L2. }\end{array}$ \\
\hline 9. & Foreignizing & $\begin{array}{l}\text { Using a LI word by adjusting it to L2 phonologically } \\
\text { (i.e., with a L2 pronunciation) and/or morphologically } \\
\text { (e.g., adding to it a L2 suffix). }\end{array}$ \\
\hline
\end{tabular}




\begin{tabular}{|l|l|l|}
\hline 10. & Code Switching & Using a LI word with LI pronunciation in L2. \\
\hline 11. & Appeal for Help & $\begin{array}{l}\text { Turning to the conversation partner for help either } \\
\text { directly (e.g. What do you call. . ?) or indirectly (e.g., } \\
\text { rising intonation, pause, eye contact, puzzled } \\
\text { expression). }\end{array}$ \\
\hline 12. & $\begin{array}{l}\text { Use of } \\
\text { Fillers/Hesitation } \\
\text { Devices }\end{array}$ & $\begin{array}{l}\text { Using filling words or gambits to fill pauses and to } \\
\text { gain time to think (e.g., well, now let me see, as a } \\
\text { matter offact). }\end{array}$ \\
\hline
\end{tabular}

The presence of oral communication strategy is even more prevalent during communication between those that are communicating in an L2 and do not share a common L1 (Yule \& Tarone, 1991, in Spromberg, 2011). To the present time, a great deal of research has been done to investigate the use of OCS. Ellis (1984, in Moattarian, 2012, p.2349) mentions that "OCS can be considered as a good notion for evaluating L2 communicative performance". Understanding the OCS employed by students can help teachers understand their strategic competence so that appropriate strategies could be chosen for pedagogical purposes. The teachers can understand a lot about the learners' knowledge by examining the OCS they employ (Moattarian, 2012).

Discussion is regarded well suited to facilitate a number of course goals. It is one of the examples of classroom speaking activities which are able to promote speaking skill (Harmer, 2001). Discussion which refers to student speaking to group members is defined as spoken communication among the students. It allows learners to practice communicating in an L2 (target language) which can provide more opportunities for language production (Mingzhi, 2005). Therefore, this study attempts to show the specific types of communication strategies that English language learners in the University of Kuningan use to communicate with one another in a group discussion. It is derived from the fact that learners in the level of university also have limited knowledge in the foreign language, so they may use oral communication strategies to overcome this problem. In reference to the rationale previously mentioned, therefore, the problems of the research are formulated as follows:

1. What types of oral communication strategies are used by students in discussions?

2. What are the students' reasons for using certain types of oral communication strategies in discussions?

\section{METHOD}

To answer the research questions, a qualitative research was adopted as the approach of this study. Qualitative research was chosen in order to explore and understand the social phenomenon (Creswell, 2009). This study was undertaken at Department of English Education in the University of Kuningan. The participants of this study were a group of five students of speaking 2 class in the academic year of $2014 / 2015$. The voluntary students participated in this study were 2 males and 3 females aged 18-25. They had been learning English for approximately 6 years. All participants involved in this study were Indonesian EFL learners or non-native English speakers, which means that English was not used in their daily communication. 
In this study, the data was collected through observation and interview. The data collected through observation was students' interaction while conducting two sessions meeting of discussions, which was then videotaped and transcribed. The topics of discussion were about 'character in Drama' and 'reading aloud poetry'. The writer then conducted face to face interviews with the participants. Semistructured interview was conducted with all students participated in this study. The semi-structured interview was conducted in order to find out the students' reasons for employing certain types of OCS while conducting discussions.

Further, the data taken from observation and semi-structured interview were analyzed qualitatively. In analyzing data, the writer used Dornyei's taxonomy of OCS (cited in Dornyei, 1995) to answer the research questions.

\section{RESULTS AND DISCUSSION}

\section{Types of oral communication strategies used by students}

The first objective of this study was designed to identify types of oral communication strategies used by second semester students of English Education Department in the University of Kuningan. Dornyei's (1995) taxonomy of communication strategies was adopted to identify types of oral communication strategies used. Within Dornyei's (1995) taxonomy, the communication strategies were divided into two main types: avoidance strategies and achievement strategies. Then, under each two main types, there exists specific types of communication strategies.

Table 2. The Frequency of Two Main Types of OCS Used

\begin{tabular}{|l|l|l|l|}
\hline No & Types of OCS & Frequency & Percentage (\%) \\
\hline 1. & $\begin{array}{l}\text { Avoidance } \\
\text { /Reduction } \\
\text { Strategies }\end{array}$ & 21 & $26.92 \%$ \\
\hline 2. & $\begin{array}{l}\text { Achievement } \\
\text { /Compensatory } \\
\text { Strategies }\end{array}$ & 57 & $73.07 \%$ \\
\hline \multicolumn{2}{|l|}{ TOTAL } & $\mathbf{7 8}$ & $\mathbf{1 0 0 \%}$ \\
\hline
\end{tabular}

message. Thus, the finding of this study

As Table 2 showed, a total of 78 communication strategies were used in this study. It was found that achievement strategies $(73.07 \%)$ were more frequently used than avoidance strategies (26.92\%). Moreover, this indicated that most of students participated in this study attempted to maintain their communication by developing an alternative plan and to solve problems in communication by expanding their communicative resources, rather than avoiding their was in line with Nakatani's (2012) study, where the students tended to use achievement strategies more than avoidance strategies in their communication. This might be because the students have been studying in the English Education Department for almost a year and their experience in learning English while they were in junior and senior high school. They were probably able to speak English regardless of their grammatical errors. Most of them attempted to speak as much and as best as they could to convey their message to their interlocutor. 
Further, the following table presents the use of specific types of communication strategies by the students in this study in terms of their frequency, percentage, and rank order

Table 3. The Frequency of Specific Types of OCS Used

\begin{tabular}{|c|c|c|c|c|c|}
\hline No & Types of OCS & Strategy & Frequency & $\begin{array}{l}\text { Percentag } \\
\text { e (\%) }\end{array}$ & $\begin{array}{l}\text { Rank } \\
\text { Order }\end{array}$ \\
\hline \multirow[t]{2}{*}{1.} & \multirow{2}{*}{$\begin{array}{l}\text { Avoidance or } \\
\text { Reduction }\end{array}$} & MA & 20 & $25.64 \%$ & 2 \\
\hline & & TA & 1 & $1.28 \%$ & 6 \\
\hline \multirow[t]{10}{*}{2.} & \multirow{10}{*}{$\begin{array}{l}\text { Achievement } \\
\text { or } \\
\text { Compensatory }\end{array}$} & UF & 40 & $51.28 \%$ & 1 \\
\hline & & $\mathrm{CS}$ & 7 & $8.97 \%$ & 3 \\
\hline & & $\mathrm{AH}$ & 3 & $3.85 \%$ & 4 \\
\hline & & UP & 3 & $3.85 \%$ & 4 \\
\hline & & UN & 2 & $2.56 \%$ & 5 \\
\hline & & $\mathrm{C}$ & 1 & $1.28 \%$ & 6 \\
\hline & & $\mathrm{F}$ & 1 & $1.28 \%$ & 6 \\
\hline & & $\mathrm{A}$ & 0 & $0 \%$ & - \\
\hline & & WC & 0 & $0 \%$ & - \\
\hline & & LT & 0 & $0 \%$ & - \\
\hline \multicolumn{3}{|c|}{ TOTAL } & 78 & $100 \%$ & \\
\hline
\end{tabular}

Then, the following section

According to the table above, the data analyzed showed that the students participated in this study used nine out of twelve communication strategy types proposed by Dornyei (1995, p.58). The finding revealed that within the specific types of avoidance strategies, $25.64 \%$ were message abandonment, and $1.28 \%$ were topic avoidance, from the total of communication strategies used.

Moreover, within the specific types of achievement strategies, $1.28 \%$ were circumlocution, $3.85 \%$ were use of allpurpose words, $2.56 \%$ were use of nonlinguistic means, $1.28 \%$ were foreignizing, 8.97\% were code-switching, $3.85 \%$ were appeal for help, and $51.28 \%$ were use of fillers/ hesitation devices. On the other hand, approximation, word coinage, and literal translation, were the strategies never used by students while conducting discussions. provided description and some information on the types of OCS used by participants, as claimed in the first research question.

\section{Avoidance or Reduction Strategies}

Under subcategory of avoidance or reduction strategies, they were message abandonment and topic avoidance as the specific types of OCS proposed by Dornyei (1995). In this study, it was found that avoidance or reduction strategies comprised $26.92 \%$ of the total strategy used by all of students while conducting discussions.

\section{Message Abandonment}

Message abandonment was designated as "incomplete sentences" (Nakatani, et al., 2012, p.72). It was found

that almost all students participated in this study used message abandonment strategy; only one of them who never used this strategy. The following excerpt of students' discussion 
Rosi Hardianti

A Study of EFL Students' Oral Communication Strategies in Discussions

illustrated how the participants used message abandonment strategy:

S2: "I think there is some character also in drama. Do you know by, do you know what we called as 'cameo'?"

S1: "Cameo? a ..., 'cameo', it's like er... (P:02)"

(S1 left her message unfinished by using fillers 'er...', then silent for more than two seconds)

In the next example, S5 used this strategy by saying "I forget" rather than silent as what $\mathrm{S} 1 \mathrm{did}$, as follow:

Ss: "What? What?"

S5: "I mean er..., in characteristic there is antagonist, protagonist, but er..., there is one more in characteristic, but I forget. Maybe you can searching in the internet!" (S5 left his message unfinished by saying 'I forget')

Based on the example above, S1 and S5 were the participants who used message abandonment strategy. Nakatani (2012, p.73) notes, "participants resorted to message abandonment as their language capability did not enable them to continue the message effectively". In this study, message abandonment strategy used for 20 times or $25.64 \%$ of the total strategy used by all of students while conducting discussions.

\section{Topic Avoidance}

Besides message abandonment strategy, topic avoidance as the other specific types of avoidance or reduction strategies proposed by Dornyei (1995) was the strategy found in this study. Topic avoidance was designated as "going off the point" (Dornyei \& Thurrell, 1992, p.71). It was found that not all students participated in this research used topic avoidance strategy; only S1 was the participant who used this strategy. The following excerpt then illustrated how topic avoidance strategy employed by participant:
Ss: "Comedian?! <LAUGH>”

S1: "I think it is about the genre?"

S2: "Huh?"

S1: "Oh, no no no <LAUGH>"

(S1 tried to go off the statement by saying "NO")

Based on the conversation above, S1 was deliberately going off the statement or topic by saying 'no' when S2 asked about her statement before. Faerch \& Kasper (1983) believed that topic avoidance occurs when the learners simply do not talk about the concepts for which the vocabulary or other meaning structure is not known for them. In such situation, learner may change the topic of discourse or remain passive (Syahrial, 2013, p.12). In this study, topic avoidance strategy was used just for once or $1.28 \%$ of the total strategy used by all participants while conducting discussions.

\section{Achievement or Compensatory Strategies} Under subcategory of achievement or compensatory strategies, they were circumlocution, use of allpurpose words, use of non-linguistic means, foreignizing, code-switching, appeal for help, and use of fillers/hesitation devices, as the specific types of OCS used by students. In this study, it was found that avoidance or reduction strategies comprised $73.07 \%$ of the total strategy used by all of students while conducting discussions. Then, each single achievement or compensatory strategy with the degree of its use then could be mentioned in the following sections:

\section{Use of Fillers}

Use of fillers was the most frequently strategy used by all students participated in this study. It was used for 40 times or comprised $51.28 \%$ of the total strategy used. The application of 
expressions such as umm..., er..., you know..., and what is it?, were the use of fillers strategy occurred in this study. These expressions were used to "fill pauses and to gain time to think" (Dornyei, 1995, p. 58). These strategy used by the participants as they wanted to keep the attention of their group members in discussion.

\section{Code Switching}

This strategy was rather frequently used by almost all students participated in this study; only S3 who did not use this strategy. While conducting discussions, participants employed code-switching strategy for 7 times or $8.97 \%$ of the total strategy used. The following excerpt was the example illustrated how this strategy used:

\section{S2: "Who is being, you know, pemeran pengganti."}

(Because S2 did not know the words of 'pemeran pengganti' in English, so she used Indonesian)

S5: "...it is er..., make me, ketagihan, enjoy." (Because S5 did not know the words of 'ketagihan' in English, so he used Indonesian)

As shown in the examples above, S2 and S5 used this strategy when they did not know the English word of 'pemeran pengganti' and 'ketagihan'. Therefore, S2 used the word 'pemeran pengganti' instead of 'stuntman' and S5 used the word 'ketagihan' instead of 'addicted'. Related to this, Syahrial (2013, p.10) pointed out that "the learners' L2 utterance will form a mixture of the target language (L2) and mother tongue (L1)". In this study, it was found that the mixture of languages formed was English and Indonesian.

\section{Appeal for Help}

This strategy was manifested in rising intonation or in directly asking for repetition or help (Nakatani, et al., 2012). In this research, it was not frequently used by all participants; only S2 who used appeal for help strategy. It was used for 3 times or comprised $3.85 \%$ of the total strategy used. For example, S2 did not know the meaning of the word "dramatical appropriateness", so she asked to one of her group members in discussion to help her in defining this term.

Then, another example of this strategy was rather different with the example previously mentioned. S2 did not know the correct word for "pembaca puisi" in English, so she asked her group members in discussion to help her in translating the word "pembaca puisi" into English. Although S2 mixed her utterances by using Indonesian, it was include in 'appeal for help' strategy since it was indicated by raising the intonation at the end of her utterances.

\section{Use of All-Purpose Words}

This strategy used by extending a general, empty lexical item to contexts where specific words are lacking (Dornyei, 1995). The words such as "thing", "stuff", and "something" frequently used by students, because these expressions assisted in sustaining conversations with the interlocutors when the exact word was not retrievable (Nakatani, et al., 2012). The following excerpt was the example illustrated how S3 used this strategy:

S3: "... because it has a lot of preparation; it takes more than a week, and then what it is? Um..., tired preparation. And I need to pick up some things, some stuffs, er..."

S3: “...in real drama also have something like that. If you watch drama on opera house or something like that, it also need stunt man, because stunt man is not only for movie or film, or something like that."

As shown in the example above, S3 used general words such as 'thing', 
'stuff', and 'something' to refer to the words she meant. In this study, this strategy was not frequently used by all participants; only S3 who used appeal for help strategy. Then, it was revealed that S3 applied this strategy for 3 times or comprised $3.85 \%$ of the total strategy used.

\section{Use of Non-Linguistic Means}

Another compensatory strategy which had low frequency was use of nonlinguistic means. Learners used specific body language to explain unfamiliar cultural expressions (Nakatani,et al., 2012, p.75). In this study, S2 and S4 were the participants who used this strategy. In the following excerpt illustrated how this strategy used by S2 and S4:

S2: "...But in reading aloud poetry in English, of course is not need. You know, what you need is only your mime sshe used her hands to describe the word 'mime'\}, and also your eye contact \{she used her hands to describe the word 'eye contact'\}, right?"

S4: "Use veil?" \{He used his hands to refer to the word 'veil'\}

As shown in the example above, S2 and S4 tried to communicate the words 'mime', 'eye contact', and 'veil' by using gesture of their hands.A few students used specific body language to explain certain words which seemed difficult to understand. In the other words, mimes and gestures are seldom used among students participated in this study. This strategy was used for twice or comprised $2.56 \%$ of the total strategy used.

\section{Circumlocution}

As explained by Dornyei (1995, p. 58), circumlocution can be understood as "describing or exemplifying the target object or action". In this study, this strategy was another compensatory strategy which had low frequency; only S3 who used this strategy. It was found that circumlocution strategy was just used once or $1.28 \%$ of the total strategy used. In the following example illustrated how circumlocution strategy used:

\section{S3: “...And the antagonist is the opposite, er... someone who act like bad way, or umm, bad guy or bad girl." (character)}

As the example of circumlocution strategy used, it showed that S3 tried to describe the word "character" any longer. S3 hence used the words "bad way, or umm, bad guy or bad girl' to refer to the word 'character'.

\section{Foreignizing}

Another compensatory strategy which participants used was foreignizing. In this study, foreignizing strategy was another compensatory strategy which had low frequency; only S3 who used this strategy. In this strategy, learners use L1 word by adjusting it to L2 phonologically (Dornyei, 1995, p.58). In the following example, S3 pronounced the word 'figuran' in Indonesia by using English pronunciation.

\section{S3: "Stunt man here is a someone who just act like er...figuran." \\ \{S3 pronounced the word 'figuran' by /figjurən/\}}

As the example above showed, S3 used the Indonesian word of 'figuran' (/figjurən/) by using English pronunciation. Then, it was found that this strategy was just used once or comprised $1.28 \%$ of the total strategy used.

On the other hand, three more types of OCS never used by students while conducting discussions, they were: approximation, word coinage, and literal translation. Approximation strategy was used to express the meaning of the target lexical item with an alternative term 
(Nakatani, et al., 2012, p.74). It was found that no students participated in this study used approximation while conducting discussions. It might be about the EFL students' knowledge of alternative term. Moreover, this strategy apparently was difficult for students as their vocabulary knowledge is still limited.

Word coinage strategy was the next compensatory strategy which refers to creating a non-existing L2 word based on a supposed rule, e.g. vegetarianist for vegetarian, paintist for painter (Dornyei, 1995, p.58). It was found that no students participated in this study used word-coinage while conducting discussions. As Rusina (2008, in Nakatani, et al., 2012, p.75) pointed out, "EFL learners are sometimes anxious about making mistakes in speaking and have a propensity to avoid speaking altogether". So, they tried to avoid making up a new word which was not exist in the target language. It might be about the fear of being laughed at if they made mistakes.

The last strategy never used by students in this study was literal translation. Literal translation strategy is defined as "translating literally a lexical item, idiom, compound word, or structure from L1 to L2" (Dornyei, 1995, p.58). It was found that no students participated in this study used literal translation strategy while conducting discussions. It probably due to the existence of native-language mindset among the students rather decreased. Although they had limited knowledge of communication in English, they tried to minimize the existence of Indonesian while communicating in English.

\section{The Students' Reasons for Using Certain Types of OCS}

The second objective of this study was to know the reasons of EFL students for using certain types of OCS in their communication. It was analyzed to get conclusion of the reason of EFL students for using certain types of OCS while conducting discussion.

Based on the answer of the first research question, the finding revealed that the highest frequency of oral communication strategy types used by all participants was allocated to the use of fillers strategy. Then, to analyze the reasons of students for using certain types of OCS, a semi-structured interview was held with participants. The data collected through a semi-structured interview then was audio-taped and transcribed. Five EFL students participated in this study were specifically asked about their reasons in choosing certain types of OCS used while conducting two sessions meeting of discussions. Based on the interview, it was found that all students participated in this study have same reasons for using fillers strategy.

The following transcript provided complete description of the students' interview result related to their reasons for using fillers strategy. It was revealed from the interview:

\#S1: "Firstly, maybe it's because I forget. Secondly, maybe it's for gaining time, because I have to think what I have to say."

\#S2: "Probably it's due to the reflex. So, when I said like that, I might have the difficulties in saying what I wanted to say directly. I still thought what I wanted to say, maybe in the aspect of its vocabulary. So, in order to remind me, I said "you know?", like that." \#S3: "It's actually to gain time because I didn't know what the English word for something. Then, to think and find the vocabulary or words I didn't know."

\#S4: “First, it's because I didn't know the vocabulary. Second, it's because to think and remind, so better for me to say 'what is it?' rather than silent, stop speaking or stuck, and seem blank." 


\section{Rosi Hardianti}

A Study of EFL Students' Oral Communication Strategies in Discussions

\#S5: “Because I didn't know; I didn't have idea in what I wanted to say. Then, I didn't know the vocabulary which was still strange."

Based on the interview above, it indicated that although the reasons conveyed by students seemed vary, however the intended meaning of their answers were generally same. The reasons of students for using fillers strategy in their communication during discussion were because they didn't know the English vocabulary for something and how to express directly what they wanted to say in English. The students frequently used fillers strategy during discussion as they tried to speak as much as they could instead of silent, although their English vocabulary and content knowledge about topic which was being discussed was still limited. It is particularly useful for language learners since they provide them with sense of security in the language by allowing them extra time and room to maneuver (Dornyei \& Thurrell, 1992). Perhaps, students frequently used fillers strategy in order to keep communication going instead of getting stuck in their communication.

\section{CONCLUSION}

Overall, students tend to use achievement or compensatory strategies more frequently than avoidance or reduction strategies indicating that most students attempt to solve problems in communication by expanding their communicative resources, rather than avoiding their message or leaving their original communication goal. For instance, the most frequent strategy used by all of students during discussions conducted is the use of fillers strategy. Then, according to the interview conducted, the students' reasons for using fillers strategy in their communication are basically because of their lack of English vocabulary knowledge and content knowledge of topic which are being discussed.

In conclusion, students encounter communication problems as the results of target linguistic inadequacy. In order to overcome these problems, the students resort to several types of communication strategies. Thus, oral communication strategy used by the students is not indicating a sign of communication failure. Conversely, communication strategies surface as the students realize that they have problems of expressing their intended meaning and they need to solve the problems.

Then, the writer suggests further researchers to continue researching on the use of oral communication strategies with different context of study, for example conducting the research in the context of informal classroom setting. Besides, the study might yield different result if the topics chosen for discussion were desired topics among students. It becomes recommendation for further researchers to conduct a further study in this field, especially for conducting the research in different classroom speaking activity, such as in debate.

\section{REFERENCES}

Brown, H. D. (2000). Principles of language learning and teaching (4th ed.). New York: Longman.

Corder, S. P. (1981). Error analysis and interlanguage. Oxford: Oxford University Press.

Creswell, J. W. (2009). Design qualitative, quantitative and mixed methods approaches ( $3 r d$ ed.). Thousand Oaks, CA: Sage.

Crystal, D. (2003). English as a global language (2nd ed.). Cambridge: Cambridge University Press.

Dornyei, Z. (1995). On the teachability of communication strategies. TESOL Quarterly, 29, 55-85. Retrieved on January 25, 2015 from 
http://www.zoltandornyei.co.uk/upload s/1995-dornyei-tq.pdf

Dornyei, Z., \& Thurrell, S. (1992).

Conversation and dialogues in action. Englewood Cliffs: Prentice Hall.

Ellis, R. (1984). Communication strategies and the evaluation of communicative performance. ELT Journal, 38(1), 39-44.

Ellis, R. (1997). Second language acquisition. Oxford: Oxford University Press.

Flyman, A. (1997). Communication strategies in French as a foreign language. Working Papers, 46, 57-73.

Harmer, J. (2001). The practice of English language teaching (3rd ed.). New York: Pearson Education Limited.

Khadidja, K. (2010). The effect of classroom interaction on developing the learner's speaking skill. (Unpublished Thesis). Constantine: Mentouri University. Retrieved on February 06, 2015 from http://bu.umc.edu.dz/theses/anglais/ KOU1159.pdf

Mingzhi, X. (2005). Enhancing interaction in our EFL classroom. CELEA Journal, 28(2), 56-62.

Moattarian, A. (2012). Iranian EFL learners' perception and performance of communication strategies in different mediums of communication. Theory and Practice in Language Studies, 2(11), 2349-2356. doi:10.4304/tpls.2.11.
Nakatani, Y., Makki, M., \& Bradley, J. (2012). 'Free' to choose: Communication strategy use in EFL classrooms in Iran. Iranian Journal of Applied Linguistics (IJAL), 15(2), 61-83.

Spromberg, S. (2011). Communication strategies used by high school English language learners in multilingual classrooms. (Unpublished Master Thesis). New York: University of New York.

Syahrial, A. (2013). communication strategies used by young learners in a billingual classroom. (Unpublished Thesis). Salatiga: Universitas Kristen Satya Wacana.

Wei, L. (2011). Communicative strategies in second language acquisition: A study of Chinese English learners' attitude and reported frequency of communicative strategies. (Unpublished Thesis). Stockholm: Kristianstad University.

Yule, G., \& Tarone, E. (1991). The other side of the page: Integrating the study of communication strategies and negotiated input in SLA. In Spromberg, S. (2011). communication strategies used by high school English language learners in multilingual classrooms. (Unpublished Master Thesis). New York: University of New York. 